\title{
In-vitro steroid synthesis by the placenta of cows in late gestation and at parturition
}

\author{
T. S. Gross* and W. F. Williams
}

Department of Animal Sciences, University of Maryland, College Park, MD 20742, USA

\begin{abstract}
Summary. Placental tissues were collected during late gestation (Group I, N = 11), pre partum (Group II, $\mathbf{N}=9$ ) and post partum $(\mathrm{N}=29)$ : 15 of the post-partum cows released the fetal membranes normally (Group III) and 14 retained the fetal membranes (Group IV). Preparations of dispersed fetal placental cells, preparations enriched in binucleate cells (BNC) or in small principal cells as well as tissue minces were utilized. Maternal placental tissue (caruncle) and fetal placental principal cells made minimal conversion of pregnenolone and androstenedione to other steroids ( $<15 \%$ conversion). Fetal placental tissue and enriched preparations of BNC were more active and were similar in their conversion of pregnenolone and androstenedione to other steroids. BNC converted pregnenolone primarily to progesterone during late gestation, but this was altered in the direction of oestrogens pre partum and post partum. BNC were capable of converting androstenedione to oestrogens, but this ability diminished greatly post partum if the fetal membranes were released normally. In-vitro treatment of fetal placental tissue minces with dexamethasone increased the conversion of pregnenolone to androstenedione and the oestrogens but did not alter the conversion of androstenedione to oestrogens. These results indicate that the fetal placental BNC are the primary cell type involved in fetal placental steroidogenesis peripartum and that dexamethasone may alter this steroidogenesis by activating the $\mathrm{C} 17,20$-lyase enzyme complex.
\end{abstract}

Keywords: cow; placenta; steroid; synthesis; peripartum

\section{Introduction}

Endocrine changes associated with parturition in cattle have been reviewed by Wagner $e$ t al. (1974) and by First (1978). The signal for parturition appears to originate in the fetal pituitary followed by a corticoid release from the fetal adrenals and a subsequent synthesis of oestrogens by the fetal placenta. Bovine peripartal placental tissue is able to synthesize progesterone (Wiener, 1976) and oestrogen (Steele et al., 1976; Evans \& Wagner, 1981; Mostl et al., 1984) in vitro. Many studies have utilized placental explants, tissue minces or dispersed cell preparations to examine placental steroidogenesis. However, the steroidogenic capacity of specific fetal placental cell types cannot be evaluated in such systems.

Several epithelial cell types have been described for the fetal trophoblastic component of bovine placental tissue (Wimsatt, 1951; Holm et al., 1964; Bjorkman, 1969; Wooding \& Wathes, 1980). Most of the epithelial cells are uninucleate principal cells while about $20 \%$ are binucleate giant cells (BNC). The BNC decline in number peripartum in sheep (Wooding, 1983) and cattle (Margolis et al., 1983; Gross et al., 1985b; Williams et al., 1987). Reimers et al. (1985) reported in-vitro progesterone synthesis by mid-gestation placental BNC. The role of specific fetal placental cells and declining BNC numbers in parturition has not yet been determined.

\footnotetext{
*Present address: Dairy Science Department, University of Florida, Gainesville, FL 3261 1, U.S.A.
} 
Examination of steroid synthesis by fetal placental cells collected peripartum before fetal placental release might indicate their involvement in parturition and placental separation. The present study was conducted to identify the specific fetal placental cells which are involved in steroidogenesis and to relate peripartal changes in this synthesis to parturition and placental separation. In addition, we describe our technique for the recovery of enriched preparations of placental BNC and principal cells of cattle.

\section{Materials and Methods}

Materials. Phosphate-buffered saline (PBS: containing $10 \mathrm{mg}$ streptomycin/l and $1 \mathrm{mg}$ penicillin/l), trypsin solution $\left(0.25 \%\right.$ in Hanks balanced salts without $\mathrm{Ca}^{2+}$ and $\mathrm{Mg}^{2+}$ ), medium (DMEM, buffered with $20 \mathrm{mM}$-Hepes; containing $1 \mathrm{gglucose} / \mathrm{l}, 1 \mathrm{~g} \mathrm{BSA} / 1,10 \mathrm{mg}$ streptomycin/l and I mg penicillin/l), Ficoll-400 (dissolved in medium), Sephadex LH-20, and trypan blue stain $(0.2 \%$ in PBS) were purchased from Sigma Chemical Co. (St Louis, MO, U.S.A.). Labelled steroids were purchased from New England Nuclear (Boston, MA, U.S.A.). Solvents for chromatographic analyses were purchased from Scientific Products (Columbia, MD, U.S.A.).

Tissue collection. Placentomes were collected from Holstein cows 10 days before expected calving (pre partum, 20 cows) or within $1 \mathrm{~h}$ after calving (post partum, 29 cows). Pre-partum placentomes were collected via Caesarean section. Food and water were withheld for 24 and $12 \mathrm{~h}$ before surgery respectively. An epidural injection of $5 \mathrm{ml} 2 \%$ lidocaine-HCl (Invenex, Chagrin Falls, OH, U.S.A.) was administered and a standing flank laparotomy was utilized to expose the reproductive tract. The uterus was opened, avoiding major vessels and the calf removed, 3-5 placentomes were excised and the uterus was closed. Oxytocin was administered to effect as needed and the flank closed. All cows were treated after surgery with penicillin and monitored for at least 5 days for signs of infection. Post-partum placentomes were collected manually, per vaginam. Of the pre-partum cows (Group I), 11 had plasma progesterone concentrations of $6.9 \pm 1.31 \mathrm{ng} / \mathrm{ml}$ during the 4 days before surgery. The remaining 9 pre-partum cows (Group II) had plasma progesterone concentrations which declined from $7 \cdot 1 \pm 1.21$ to $3.5 \pm 0.81 \mathrm{ng} / \mathrm{ml}$ during the 4 days before surgery, indicating that they were approaching parturition. Of the post-partum cows, 15 calved spontaneously and released the fetal placental membranes within $12 \mathrm{~h}$ after calving (Group III), and 14 calved spontaneously and retained the fetal placental membranes for longer than $12 \mathrm{~h}$ after calving (Group IV).

Preparation of tissue minces and dispersed cells. Fetal villi and maternal crypt placentomal components were manually separated and each was placed in fresh cold PBS. Before mincing, tissues were examined under a dissecting microscope and extraneous tissue was removed. Each tissue was then minced and the minces were rinsed twice with fresh cold PBS. Portions of the fetal villar tissue minces were placed into $250 \mathrm{ml}$ flasks $(\sim 50 \mathrm{~g}$ tissue/flask $)$ which contained $75 \mathrm{ml}$ trypsin solution. Each fetal tissue sample was digested for $10 \mathrm{~min}$ at $37^{\circ} \mathrm{C}$ and the digested portion was discarded. Fresh trypsin solution $(75 \mathrm{ml})$ was added and digestion was continued for $35-45 \mathrm{~min}$ at $37^{\circ} \mathrm{C}$. This material was filtered through 3 layers of cheese cloth and any undigested portion was discarded. The filtrate (dispersed cells) was centrifuged at $100 \mathrm{~g}$ for $15 \mathrm{~min}$ and the pelleted cells were resuspended and washed twice with cold sterile medium. The final wash yielded the dispersed cell preparation.

$B N C$ and principal cell separation. Portions of the dispersed fetal villar cell preparations were overlayered onto a discontinuous Ficoll gradient $(10 \mathrm{ml}$ dispersed cells over $10 \mathrm{ml} \%$ Ficoll over $10 \mathrm{ml} \%$ Ficoll over $10 \mathrm{ml} 6 \%$ Ficoll over $10 \mathrm{ml} 8 \%$ Ficoll) in $60 \mathrm{ml}$ glass centrifuge tubes and centrifuged at $100 \mathrm{~g}$ for $5 \mathrm{~min}$. Fractions (10 ml) were aspirated and each of the 5 was examined in a haemocytometer for cell numbers, and percentage of viable cells (trypan blue exclusion). Binucleate cells were determined by examination of Wrights' stained heat-killed cells in an aliquant from each fraction. Fractions were pooled when necessary to yield enriched BNC and small uninucleate principal cell preparations.

Tissue and cell incubations. Maternal crypt and fetal villi minces were distributed randomly into $60 \times 15 \mathrm{~mm}$ Petri dishes ( $\sim 400-500 \mathrm{mg}$ tissue/dish) containing $5 \mathrm{ml}$ medium and each was assigned to one of the various incubation groups. Incubation groups were (1) $1 \mu \mathrm{Ci}\left[{ }^{3} \mathrm{H}\right]$ pregnenolone substrate, (2) $1 \mu \mathrm{Ci}\left[{ }^{3} \mathrm{H}\right]$ pregnenolone and $400 \mathrm{ng}$ unlabelled pregnenolone substrate, (3) $1 \mu \mathrm{Ci}\left[{ }^{3} \mathrm{H}\right]$ androstenedione substrate, and (4) $1 \mu \mathrm{Ci}\left[{ }^{3} \mathrm{H}\right]$ androstenedione and $400 \mathrm{ng}$ unlabelled androstenedione substrate. All incubations were conducted in duplicate at $37^{\circ} \mathrm{C}$ for $4 \mathrm{~h}$. Fetal villi tissue minces were also distributed randomly into $60 \times 15 \mathrm{~mm}$ Petri dishes containing $5 \mathrm{ml}$ medium and assigned to two different incubation conditions (four treatment groups): Condition 1-tissue minces incubated with (Group I) and without (Group II) dexamethasone $(400 \mathrm{ng} / 5 \mathrm{ml})$ for $4 \mathrm{~h}$ at $37^{\circ} \mathrm{C}$ before the addition of labelled substrate $(4 \mathrm{~h}$ pre-incubated) and an additional $4 \mathrm{~h}$ of incubation; Condition $2-$ tissue minces incubated for $4 \mathrm{~h}$ at $37^{\circ} \mathrm{C}$ before the addition of labelled substrate (co-incubation) and a subsequent incubation for $4 \mathrm{~h}$ at $37^{\circ} \mathrm{C}$, with (Group III) and without (Group IV) dexamethasone $(400 \mathrm{ng} / 5 \mathrm{ml}$ ). Tissues within each of these conditions and groups were incubated in duplicate with $1 \mu \mathrm{Ci}\left[{ }^{3} \mathrm{H}\right]$ pregnenolone or with $1 \mu \mathrm{Ci}\left[{ }^{3} \mathrm{H}\right]$ androstenedione as labelled substrates. Villous tissue yielded approximately $2 \times 10^{6}$ cells $/ 500 \mathrm{mg}$ tissue when trypsin digested. Uninucleate small cells, including principal cells, normally constitute $\sim 75 \%$ and BNC $20-25 \%$ of the total villi cells (this study; Wooding, 1983; Williams et al., 
1987). To maintain this approximate relationship representative of the ratio found in the dispersed cell preparations, dispersed villi cells $\left(2 \times 10^{6}\right.$ cells $)$, isolated principal cells $\left(1.5 \times 10^{6}\right.$ cells $)$ and isolated BNC $\left(0.5 \times 10^{6}\right.$ cells $)$ were each distributed randomly into $16 \times 100 \mathrm{~mm}$ glass culture tubes containing $5 \mathrm{ml}$ medium. Duplicate tubes for each cell preparation involved additions of $1 \mu \mathrm{Ci}\left[{ }^{3} \mathrm{H}\right]$ pregnenolone or $1 \mu \mathrm{Ci}\left[{ }^{3} \mathrm{H}\right]$ androstenedione as labelled substrate and were incubated for $4 \mathrm{~h}$ at $37^{\circ} \mathrm{C}$.

All incubations were conducted in a closed chamber (Bellco Glass Co., Vineland, NJ, U.S.A.) under $95 \% \mathrm{O}_{2}: 5 \%$ $\mathrm{CO}_{2}$ while being agitated on a rocker platform (Bellco Glass Co.). After incubation, the samples were chilled on ice and centrifuged at $11000 \mathrm{~g}$ for $30 \mathrm{~min}$ at $4^{\circ} \mathrm{C}$. The media were decanted, the tissue blotted, wet weights obtained and the media frozen $\left(-20^{\circ} \mathrm{C}\right)$ until analysed.

Plasma progesterone analysis. Progesterone was measured in plasma samples from the pre-partum cows by using a progesterone radioimmunoassay protocol described by Knight et al. (1977) and modified in this laboratory to use an antibody characterized by Butcher (1977). The single extraction that was involved gave an extraction efficiency of $75.4 \pm 4.2 \%$. Assay data were computed and corrected for extraction efficiency using a programme developed in this laboratory by English (1981). Inter- and intra-assay coefficients of variation were 9.8 and $12.2 \%$ respectively, with a minimum sensitivity of $75.4 \pm 10.2 \mathrm{pg} / \mathrm{ml}$.

Chromatographic analysis. Media samples were analysed for the production of various labelled steroid metabolites via Sephadex LH-20 column chromatography (Wise \& Fields, 1978) with $\left[{ }^{14} \mathrm{C}\right]$ androstenedione as an internal standard and column marker. Samples $(2 \mathrm{ml})$ were extracted with $6 \mathrm{ml}$ chloroform:methanol $(3: 1, \mathrm{v} / \mathrm{v})$ taken to dryness under $\mathrm{N}_{2}$, and redissolved in $0.5 \mathrm{ml}$ of cyclohexane:benzene:methanol (90:25:5, by vol.) for addition to $1 \times 20 \mathrm{~cm}$ columns. The extraction procedure did not allow for the determination of conjugated oestrogens which remained in the aqueous fraction. Sixty fractions $(1 \mathrm{ml})$ were collected and counted for ${ }^{3} \mathrm{H}$ and ${ }^{14} \mathrm{C}$. Tritium count data were corrected for the presence of ${ }^{14} \mathrm{C}$ and the corrected ${ }^{3} \mathrm{H}$ counts were then computed per $500 \mathrm{mg}$ wet tissue weight. The chromatographic profiles for each column were plotted, the areas determined for each peak, and the results expressed as a percentage of the total profile area (\% conversion). Labelled standards for $\left[{ }^{3} \mathrm{H}\right]$ pregnenolone, $\left[{ }^{3} \mathrm{H}\right]$ progesterone, $\left[{ }^{14} \mathrm{C}\right]$ androstenedione, $\left[{ }^{3} \mathrm{H}\right]$ oestradiol, $\left[{ }^{14} \mathrm{C}\right]$ oestrone and $\left[{ }^{14} \mathrm{C}\right]$ testosterone were chromatographed to validate and identify peaks. Labelled standard recoveries were greater than $90 \%$. Only oestradiol and oestrone exhibited a major overlap of peaks, therefore the results are expressed as the percentage conversion $/ 500 \mathrm{mg}$ tissue to the products progesterone, androstenedione, oestrogens (oestradiol and oestrone peaks pooled), testosterone and unidentified products.

Further validation of each fraction was conducted using immunoreactivity with specific steroid antisera. Incubation with saturating amounts of antisera followed by charcoal-dextran separation of unbound label were used to determine the percentage of label in each fraction which bound to each specific antiserum. Progesterone antiserum (cross-reactivity: progesterone, 100\%; pregnenolone, 15\%; oestrogens and androgens, $<3 \%$ ) bound $83 \pm 6 \%$ of the label in the progesterone fraction and less than $10 \%$ of the other fractions. Testosterone antiserum (cross-reactivity: testosterone, $100 \%$; other steroids, $<2 \%$ ) bound $90 \pm 5 \%$ of the label in the testosterone fraction and less than $10 \%$ of the other fractions. The oestrogen antiserum (cross-reactivity: oestradiol, $100 \%$; oestrone, $90 \%$; other steroids, $<5 \%$ ) bound $86 \pm 6 \%$ of the label in the oestrogen fractions and less than $10 \%$ of the other fractions.

Statistics. Data were analysed with the general linear models procedure (GLM) of the Statistical Analysis System (SAS, 1982). Experimental groups and treatments were compared using a multivariate analysis of variance (MANOVA) to test whether total chromatograph profile differed for different experimental groups and treatments. Various steroid metabolites within each experimental group were compared using a randomized block analysis of variance procedure (ANOVA). When significant interactions were observed, then differences were detected via multiple comparison testing (Student-Newman-Kuels multiple range test; SNK). Multiple comparisons testing requires an adjustment of the experiment wise error to 0.05 using Bonferroni's inequality value. Error adjustment did not affect the interpretation of significant differences; results are therefore reported at an $\alpha=0 \cdot 05$.

\section{Results}

\section{Characterization of cell preparations}

Utilization of the discontinuous Ficoll gradient for fractionation of dispersed fetal placental cell preparations yielded enriched preparations of mononuclear cells $(85 \cdot 3 \pm 8 \cdot 41 \%)$ and BNC $(81 \cdot 4 \pm 6 \cdot 6 \%)$. The first and second $10 \mathrm{ml}$ fractions contained primarily uninucleate principal cells and fibroblasts, the third and fourth $10 \mathrm{ml}$ fractions contained primarily BNC and the last (5th) $10 \mathrm{ml}$ fraction contained primarily other cell types (red blood cells, fibroblasts, unidentified cells and cell/tissue clumps). Cell viability for the principal cell preparations $(91 \pm 4 \cdot 2 \%)$ did not differ between the experimental groups and did not change after incubation $(90 \pm 5 \cdot 1 \%)$. BNC viability was reduced in the post-partum experimental groups (Group I, $93 \pm 5 \%$; Group II, $91 \pm 4 \%$; Group III, $29 \pm 6 \%$; and Group IV, $69 \pm 9 \%$ ) but was not altered after incubation (Group I, $91 \pm 3 \%$; Group II, $90 \pm 4 \%$; Group III, $29 \pm 4 \%$; and Group IV, $67 \pm 3 \%$ ). 


\section{Conversion of pregnenolone}

Maternal placental crypt tissue minces were capable of a low rate of conversion of $\left[{ }^{3} \mathrm{H}\right]$ pregnenolone to the measured steroid products. Less than $15 \%$ of the labelled substrate was converted to other steroids during the 4-h incubation and the experimental groups did not differ $(P>0.05)$. Additional unlabelled pregnenolone had no effect $(P>0.05)$ on maternal tissue conversion of $\left[{ }^{3} \mathrm{H}\right]$ pregnenolone to the measured steroid products.

Fetal placental villi tissue minces converted more $\left[{ }^{3} \mathrm{H}\right]$ pregnenolone to the measured steroid products than did the maternal placental tissue minces $(P<0.05$; Table 1). Late gestation fetal villi minces (Group I) converted $\left[{ }^{3} \mathrm{H}\right]$ pregnenolone to progesterone and small amounts of other steroid products. Pre-partum fetal villi minces (Group II) converted $\left[{ }^{3} \mathrm{H}\right]$ pregnenolone to progesterone in amounts similar to that for the late gestation tissue $(P>0.05)$ and to androstenedione and oestrogen in amounts greater than that observed for the late gestation tissue $(P<0.05)$. Total conversion of $\left[{ }^{3} \mathrm{H}\right]$ pregnenolone to steroid products was not altered post partum $(P>0.05)$ if the fetal membranes were subsequently retained (Group IV), but were reduced post partum $(P<0.05)$ if the fetal membranes were subsequently released (Group III). The types of steroids produced differed, however, between the pre-partum and the post-partum groups $(P<0.05)$. Retained fetal placental tissue (Group IV) converted [ $\left.{ }^{3} \mathrm{H}\right]$ pregnenolone predominantly to oestrogen $(P<0.05)$ but tissue minces from Group III converted less $\left[{ }^{3} \mathrm{H}\right]$ pregnenolone to oestrogen than did fetal villi minces from the other experimental groups $(P<0.05)$. Additional unlabelled pregnenolone ( $400 \mathrm{ng}$ ) had no effect on the ability of fetal placental tissue to convert $\left[{ }^{3} \mathrm{H}\right]$ pregnenolone to the measured steroid products. Conversion was also unaffected by preincubation for $4 \mathrm{~h}$ before the addition of labelled substrate $(P>0 \cdot 05)$.

Table 1. Percentage conversion of $\left[{ }^{3} \mathrm{H}\right]$ pregnenolone by fetal placental tissue of cows* without and with dexamethasone ( $4 \mathrm{~h}$ preincubation)

\begin{tabular}{|c|c|c|c|c|}
\hline Steroid product & $\begin{array}{l}\text { Group } \\
\text { I }\end{array}$ & $\begin{array}{l}\text { Group } \\
\text { II }\end{array}$ & $\begin{array}{c}\text { Group } \\
\text { III }\end{array}$ & $\begin{array}{c}\text { Group } \\
\text { IV }\end{array}$ \\
\hline \multicolumn{5}{|c|}{ Without dexamethasone } \\
\hline Progesterone & $25 \pm 4-9^{\mathrm{ax}}$ & $16 \pm 2 \cdot 2^{\mathrm{ax}}$ & $3 \pm 1 \cdot 0^{b x}$ & $4 \pm 0 \cdot 7^{b x}$ \\
\hline Androstenedione & $4 \pm 0.6^{\text {by }}$ & $8 \pm 1 \cdot 3^{\text {ay }}$ & $3 \pm 1 \cdot 1^{b x}$ & $5 \pm 1 \cdot 3^{\mathrm{abx}}$ \\
\hline Oestrogens & $3 \pm 0 \cdot 8^{\text {ay }}$ & $23 \pm 0 \cdot 9^{\mathrm{ex}}$ & $9 \pm 0.9^{\text {by }}$ & $25 \pm 1 \cdot 1^{\mathrm{cy}}$ \\
\hline Unidentified & $9 \pm 2 \cdot 5^{a}$ & $10 \pm 1 \cdot 6^{\mathrm{a}}$ & $8 \pm 1 \cdot 7^{a}$ & $11 \pm 2 \cdot 3^{\mathrm{a}}$ \\
\hline \multicolumn{5}{|l|}{ With dexamethasone } \\
\hline Progesterone & $15 \pm 1 \cdot 1^{\mathrm{ax}}$ & $11 \pm 1 \cdot 3^{\mathrm{ax}}$ & $4 \pm 0.7^{b x}$ & $5 \pm 0 \cdot 6^{6 x}$ \\
\hline Androstenedione & $9 \pm 1 \cdot 2^{a y}$ & $11 \pm 0 \cdot 9^{\mathrm{ax}}$ & $4 \pm 0 \cdot 7^{b x}$ & $10 \pm 2 \cdot 0^{\text {ay }}$ \\
\hline Oestrogens & $26 \pm 1 \cdot 8^{a z}$ & $31 \pm 2 \cdot 0^{\mathrm{ay}}$ & $10 \pm 0.9^{\text {by }}$ & $30 \pm 2 \cdot 0^{\mathrm{az}}$ \\
\hline Unidentified & $10 \pm 4 \cdot 1^{\mathrm{a}}$ & $9 \pm 2 \cdot 6^{a}$ & $7 \pm 2 \cdot 3^{a}$ & $8 \pm 1 \cdot 9^{a}$ \\
\hline
\end{tabular}

Values are mean \pm s.e. for $\%$ of total chromatograph profile area.

${ }^{*}$ Group $\mathrm{I}, \mathrm{N}=11,10$ days pre partum, plasma progesterone concentrations maintained; Group II, $N=9,10$ days pre partum, plasma progesterone concentrations declining; Group III, $\mathrm{N}=15,1 \mathrm{~h}$ post partum, fetal membranes released; Group IV, $\mathrm{N}=14,1 \mathrm{~h}$ post partum, fetal membranes retained.

a,b,c Within rows, means with different superscript letters differ $(P<0.05)$.

${ }^{x, y, z}$ Within columns, means with different superscript letters differ $(P<0.05)$.

Co-incubation of fetal villi minces with dexamethasone did not affect the conversion of $\left[{ }^{3} \mathrm{H}\right]$ pregnenolone $(P>0.05)$ to the measured steroid products. However, preincubation of fetal villi minces with dexamethasone for $4 \mathrm{~h}$ before the addition of $\left[{ }^{3} \mathrm{H}\right]$ pregnenolone substrate increased the conversion of label to the measured steroid products $(P<0.05$; Table 1). Preincubation with dexamethasone decreased conversion of $\left[{ }^{3} \mathrm{H}\right]$ pregnenolone to progesterone $(P<0.05)$ and 
increased conversion of labelled substrate into oestrogen $(P<0.05)$. Although the effects of dexamethasone preincubation were greatest for the late gestation cows (Group I), significant effects were also observed for the other experimental groups.

The conversion of $\left[{ }^{3} \mathrm{H}\right]$ pregnenolone substrate by enriched fetal principal cell preparations to the measured steroid products was low $(<15 \%)$ and did not differ between the experimental groups $(P>0.05$; Table 2$)$. Conversion of $\left[{ }^{3} \mathrm{H}\right]$ pregnenolone to the measured steroid products by dispersed fetal villi cells (Table 2), BNC (Table 2$)$ and fetal villi minces (Table 1) did not differ $(P>0.05)$.

Table 2. Percentage conversion of $\left[{ }^{3} \mathrm{H}\right]$ pregnenolone by dispersed fetal placental cells and binucleate cells (BNC) of cows*

\begin{tabular}{|c|c|c|c|c|}
\hline Steroid product & $\underset{\text { I }}{\text { Group }}$ & $\begin{array}{l}\text { Group } \\
\text { II }\end{array}$ & $\underset{\text { III }}{\text { Group }}$ & $\begin{array}{c}\text { Group } \\
\text { IV }\end{array}$ \\
\hline $\begin{array}{l}\text { Dispersed cells } \\
\text { Progesterone } \\
\text { Androstenedione } \\
\text { Oestrogens } \\
\text { Unidentified }\end{array}$ & $\begin{array}{r}28 \pm 3 \cdot 9^{\mathrm{ax}} \\
5 \pm 0 \cdot 6^{\mathrm{ay}} \\
8 \pm 1 \cdot 3^{\mathrm{ay}} \\
9 \pm 2 \cdot 3^{\mathrm{a}}\end{array}$ & $\begin{array}{l}19 \pm 3 \cdot 1^{\mathrm{ax}} \\
10 \pm 1 \cdot 3^{\mathrm{by}} \\
26 \pm 2 \cdot 6^{\mathrm{bx}} \\
10 \pm 3 \cdot 1^{\mathrm{a}}\end{array}$ & $\begin{array}{r}7 \pm 1 \cdot 5^{\mathrm{bxy}} \\
5 \pm 0 \cdot 6^{\mathrm{ax}} \\
10 \pm 1 \cdot 6^{\mathrm{ay}} \\
6 \pm 2 \cdot 0^{\mathrm{a}}\end{array}$ & $\begin{array}{r}6 \pm 1 \cdot 4^{\mathrm{bx}} \\
4 \pm 1 \cdot 0^{\mathrm{ax}} \\
28 \pm 2 \cdot 1^{\mathrm{by}} \\
9 \pm 1 \cdot 7^{\mathrm{a}}\end{array}$ \\
\hline $\begin{array}{l}\text { Binucleate cells (BNC } \\
\text { Progesterone } \\
\text { Androstenedione } \\
\text { Oestrogens } \\
\text { Unidentified }\end{array}$ & $\begin{aligned} & 22 \pm 3 \cdot 3^{\mathrm{ax}} \\
& 7 \pm 1 \cdot 0^{\mathrm{aby}} \pm 1 \cdot 2^{\mathrm{ay}} \\
& 10 \pm \pm 2 \cdot 1^{\mathrm{a}} \\
& 8 \pm\end{aligned}$ & $\begin{array}{r}15 \pm 2 \cdot 9^{\mathrm{ax}} \\
13 \pm 2 \cdot 7^{\mathrm{ax}} \\
17 \pm 2 \cdot 2^{\mathrm{bx}} \\
9 \pm 3 \cdot 3^{\mathrm{a}}\end{array}$ & $\begin{array}{r}5 \pm 1 \cdot 0^{\mathrm{bx}} \\
4 \pm 0 \cdot 7^{\mathrm{bx}} \\
11 \pm 1 \cdot 1^{\mathrm{ay}} \\
7 \pm 1 \cdot 9^{\mathrm{a}}\end{array}$ & $\begin{array}{r}5 \pm 1 \cdot 2^{\mathrm{bx}} \\
6 \pm 1 \cdot 0^{\mathrm{bx}} \\
29 \pm 2 \cdot 1^{\mathrm{cy}} \\
11 \pm 4 \cdot 1^{\mathrm{a}}\end{array}$ \\
\hline $\begin{array}{l}\text { Principal cells } \\
\text { Progesterone } \\
\text { Androstenedione } \\
\text { Oestrogens } \\
\text { Unidentified }\end{array}$ & $\begin{array}{l}8 \pm 1 \cdot 9^{a x} \\
5 \pm 0 \cdot 7^{a x} \\
9 \pm 2 \cdot 2^{a x} \\
5 \pm 1 \cdot 8^{a}\end{array}$ & $\begin{array}{l}7 \pm 1 \cdot 3^{\mathrm{ax}} \\
4 \pm 1 \cdot 0^{\mathrm{ax}} \\
8 \pm 1 \cdot 7^{\mathrm{ax}} \\
5 \pm 1 \cdot 0^{\mathrm{a}}\end{array}$ & $\begin{array}{l}4 \pm 0 \cdot 7^{\mathrm{ax}} \\
5 \pm 0 \cdot 7^{\mathrm{ax}} \\
7 \pm 1 \cdot 5^{\mathrm{ax}} \\
5 \pm 1 \cdot 6^{\mathrm{a}}\end{array}$ & $\begin{array}{l}3 \pm 1 \cdot 1^{\mathrm{ax}} \\
4 \pm 1 \cdot 0^{\mathrm{ax}} \\
6 \pm 2 \cdot 0^{\mathrm{ax}} \\
5 \pm 2 \cdot 2^{\mathrm{a}}\end{array}$ \\
\hline
\end{tabular}

Values are mean \pm s.e. for $\%$ of total chromatograph profile area.

${ }^{*}$ Group I, $\mathrm{N}=11,10$ days pre partum, plasma progesterone concentrations maintained; Group II, $N=9,10$ days pre partum, plasma progesterone concentrations declining; Group III, $\mathrm{N}=15,1 \mathrm{~h}$ post partum, fetal membranes released; Group IV, $\mathrm{N}=14,1 \mathrm{~h}$ post partum, fetal membranes retained.

${ }^{a, b, c}$ Within rows, means with different superscript letters differ $(P<0.05)$.

${ }^{\mathrm{x} .}{ }^{\mathrm{y}}$ Within columns and cell types, means with different superscript letters $\operatorname{differ}(P<0.05)$.

\section{Conversion of androstenedione}

Maternal placental crypt minces were capable of a low rate of conversion of $\left[{ }^{3} \mathrm{H}\right]$ androstenedione to the measured steroid products. Less than $15 \%$ of the labelled substrate was converted to other steroid products and the experimental groups did not differ $(P>0.05)$. Additional unlabelled androstenedione $(400 \mathrm{ng})$ did not affect the ability of these minces to convert $\left[{ }^{3} \mathrm{H}\right]$ androstenedione to the measured steroid products $(P>0.05)$.

Fetal placental villi minces converted more $\left[{ }^{3} \mathrm{H}\right]$ androstenedione to the measured steroid products than did the maternal placental minces $(P<0.05$; Table 3$)$. Fetal villi minces from Groups I, II and IV converted $\left[{ }^{3} \mathrm{H}\right]$ androstenedione to oestrogen in similar amounts $(P>0.05)$ but tissue minces from Group III showed less oestrogen production $(P<0.05)$. Conversion of $\left[{ }^{3} \mathrm{H}\right]$ androstenedione to the measured steroid products by fetal villi minces was unaffected by preincubation for $4 \mathrm{~h}$ before the addition of labelled substrate $(P>0.05)$. Neither coincubation nor $4 \mathrm{~h}$ preincubation with $400 \mathrm{ng}$ dexamethasone affected conversion of $\left[{ }^{3} \mathrm{H}\right]$ androstenedione to the measured steroid products by fetal villi minces $(P>0.05)$. 
Table 3. Percentage conversion of $\left[{ }^{3} \mathrm{H}\right]$ androstenedione by fetal placental tissue of cows*

\begin{tabular}{lrrrr}
\hline $\begin{array}{l}\text { Steroid } \\
\text { product }\end{array}$ & $\begin{array}{c}\text { Group } \\
\text { I }\end{array}$ & $\begin{array}{c}\text { Group } \\
\text { II }\end{array}$ & \multicolumn{1}{c}{$\begin{array}{c}\text { Group } \\
\text { III }\end{array}$} & \multicolumn{1}{c}{$\begin{array}{c}\text { Group } \\
\text { IV }\end{array}$} \\
\hline Oestradiol & $30 \pm 3 \cdot 4^{\mathrm{a}}$ & $37 \pm 3 \cdot 6^{\mathrm{a}}$ & $13 \pm 1 \cdot 4^{\mathrm{b}}$ & $31 \pm 2 \cdot 3^{\mathrm{a}}$ \\
Testosterone & $4 \pm 0 \cdot 7^{\mathrm{a}}$ & $7 \pm 1 \cdot 2^{\mathrm{a}}$ & $5 \pm 0 \cdot 8^{\mathrm{a}}$ & $6 \pm 1 \cdot 0^{\mathrm{a}}$ \\
Unidentified & $12 \pm 2 \cdot 4^{\mathrm{a}}$ & $15 \pm 3 \cdot 7^{\mathrm{a}}$ & $9 \pm 4 \cdot 0^{\mathrm{a}}$ & $13 \pm 3 \cdot 4^{\mathrm{a}}$ \\
\hline
\end{tabular}

Values are mean \pm s.e. for $\%$ of total chromatograph profile area.

${ }^{*}$ Group I, $\mathrm{N}=11,10$ days pre partum, plasma progesterone concentrations maintained; Group II, $\mathrm{N}=9,10$ days pre partum, plasma progesterone concentrations declining; Group III, $\mathrm{N}=15,1 \mathrm{~h}$ post partum, fetal membranes released; Group IV, $\mathrm{N}=14,1 \mathrm{~h}$ post partum, fetal membranes retained.

${ }^{\mathrm{a}, \mathrm{b}}$ Within rows, means with different superscript letters differ $(P<0.05)$.

Table 4. Percentage conversion of $\left[{ }^{3} \mathrm{H}\right]$ androstenedione by dispersed fetal placental cells, principal cells and binucleate cells (BNC) of cows*

\begin{tabular}{|c|c|c|c|c|}
\hline $\begin{array}{l}\text { Steroid } \\
\text { product }\end{array}$ & $\underset{\text { I }}{\text { Group }}$ & $\begin{array}{c}\text { Group } \\
\text { II }\end{array}$ & $\begin{array}{l}\text { Group } \\
\text { III }\end{array}$ & $\begin{array}{l}\text { Group } \\
\text { IV }\end{array}$ \\
\hline \multicolumn{5}{|l|}{ Dispersed cells } \\
\hline Oestrogens & $31 \pm 1.9^{\mathrm{a}}$ & $35 \pm 2 \cdot 7^{a}$ & $10 \pm 0 \cdot 7^{b}$ & $28 \pm 1 \cdot 5^{a}$ \\
\hline Testosterone & $5 \pm 1 \cdot 0^{\mathrm{a}}$ & $4 \pm 0 \cdot 7^{2}$ & $4 \pm 1 \cdot 5^{\mathrm{a}}$ & $8 \pm 1 \cdot 4^{a}$ \\
\hline Unidentified & $11 \pm 2 \cdot 5^{a}$ & $12 \pm 3 \cdot 0^{2}$ & $9 \pm 3 \cdot 1^{a}$ & $12 \pm 2 \cdot 7^{a}$ \\
\hline \multicolumn{5}{|c|}{ Binucleate cells (BNC) } \\
\hline Oestrogens & $28 \pm 2 \cdot 5^{\mathrm{a}}$ & $33 \pm 1 \cdot 9^{a}$ & $8 \pm 0.7^{b}$ & $25 \pm 2 \cdot 0^{a}$ \\
\hline Testosterone & $3 \pm 0 \cdot 7^{a}$ & $7 \pm 1 \cdot 4^{2}$ & $5 \pm 0 \cdot 8^{\mathrm{a}}$ & $6 \pm 1 \cdot 0^{\mathrm{a}}$ \\
\hline Unidentified & $9 \pm 2 \cdot 1^{a}$ & $11 \pm 3 \cdot 3^{3}$ & $11 \pm 2 \cdot 0^{\mathrm{a}}$ & $12 \pm 2 \cdot 7^{\mathrm{a}}$ \\
\hline \multicolumn{5}{|l|}{ Principal cells } \\
\hline Oestrogens & $14 \pm 1 \cdot 5^{a}$ & $13 \pm 1 \cdot 1^{a}$ & $9 \pm 1 \cdot 3^{a}$ & $12 \pm 1 \cdot 0^{\mathrm{a}}$ \\
\hline Testosterone & $4 \pm 1 \cdot 0^{\mathrm{a}}$ & $3 \pm 1 \cdot 0^{a}$ & $2 \pm 0.4^{a}$ & $2 \pm 0 \cdot 6^{\mathrm{a}}$ \\
\hline Unidentified & $8 \pm 2 \cdot 3^{a}$ & $7 \pm 1 \cdot 2^{a}$ & $6 \pm 2 \cdot 1^{2}$ & $9 \pm 1 \cdot 6^{a}$ \\
\hline
\end{tabular}

Values are mean \pm s.e. for $\%$ of total chromatograph profile area.

*Group I, N =11, 10 days pre partum, plasma progesterone concentrations maintained; Group II, $\mathrm{N}=9,10$ days pre partum, plasma progesterone concentrations declining; Group III, $\mathrm{N}=15,1 \mathrm{~h}$ post partum, fetal membranes released; Group IV, $\mathrm{N}=14,1 \mathrm{~h}$ post partum, fetal membranes retained.

${ }^{\mathrm{a}, \mathrm{b}}$ Within rows, means with different superscript letters differ $(P<0.05)$.

Conversion of $\left[{ }^{3} \mathrm{H}\right]$ androstenedione to the measured steroid products by enriched fetal principal cell preparations was low and did not differ between experimental groups $(P>0.05$; Table 4$)$. Conversion of $\left[{ }^{3} \mathrm{H}\right]$ androstenedione to the measured steroid products, especially oestrogen, was greater by the dispersed fetal placental cells (Table 4), the BNC preparations (Table 4) and the fetal villi minces (Table 3 ), which however, did not differ between experimental groups $(P>0.05)$.

\section{Discussion}

Our results demonstrate that the bovine fetal placental villi are more active in steroid synthesis on a wet weight basis than are the maternal placental caruncular crypt components. This is in agreement 
with the data by Hoffmann et al. (1977) who concluded that the fetal cotyledon is the primary site of placental oestrogen synthesis. Our data also confirm that bovine fetal villi tissue is capable of converting C21 (pregnenolone) and C19 (androstenedione) precursors to oestrogens as was reported by Evans \& Wagner (1981).

Wiener (1976) demonstrated that the bovine placenta from the peripartum period is capable of progestagen synthesis. Our results demonstrate that fetal villi from late gestation and immediately pre-partum are capable of progesterone synthesis from pregnenolone. The corpus luteum is considered to be the primary source of progesterone during late gestation in cattle (Wagner et al., 1974; First, 1978). Maternal plasma progesterone concentrations decrease in cows which are ovariectomized during late gestation, but occasionally the progesterone concentration may be maintained at lower levels and the pregnancy proceed to term (Estergreen et al., 1967; First, 1978; Chew et al., 1979; Gross et al., 1985a). This suggests that the bovine placenta and/or the adrenal may be important sources of progesterone during late gestation. Our results indicate a decrease in fetal villi progesterone synthesis and an increase in oestrogen synthesis immediately before parturition. This indicates that progesterone is no longer the primary end product of fetal villi steroid synthesis and that conversion to other steroid products (e.g. androstenedione and oestrogens) is occurring during this peripartum period.

Reimers et al. (1985) demonstrated that the BNC from mid-gestation fetal villi produce progesterone in vitro. Our results demonstrate that the BNC are the primary site of fetal placental steroid synthesis (progesterone and oestrogens) in the cow during late gestation and during the peripartum period. Preparations of fetal principal cells were contaminated with other uninuclear cells such as fibroblasts, but steroidogenic activity was very low with these preparations and did not differ between experimental groups.

The ability of fetal villi minces to produce oestrogens from pregnenolone or androstenedione substrates increased pre partum. This is in agreement with the findings of Ainsworth \& Ryan (1966) and Evans \& Wagner (1981) who demonstrated an increase in the aromatase activity of bovine placental tissue at this time. They also indicated that aromatase activity remains increased in early post-partum placental tissue. We have observed a continuation of this increased aromatase activity immediately post partum if the fetal membranes are subsequently retained, but not if the fetal membranes are subsequently released normally. This suggests that maintenance of fetal villi aromatase activity post partum may be related to placental retention. Garverick et al. (1974) have reported lower maternal peripheral plasma oestrogen concentrations in cows which retain the fetal membranes. However, these were peripheral oestrogen concentrations which may not be fully indicative of localized placental oestrogen concentrations or synthesis. Likewise, in-vitro placental oestrogen synthesis may not be related to fetal membrane retention except as it may indicate cellular changes in the tissue. Our earlier reports (Margolis et al., 1983; Gross et al., 1985b; Williams et al., 1987) have demonstrated that fetal placental BNC decline in number in the immediate peripartum period if the fetal membranes are subsequently released normally. Decreasing fetal placental aromatase in cows which subsequently release the fetal membranes may reflect a decline in BNC numbers. Therefore, the continuation of oestrogen synthesis by fetal villi in cows which subsequently retain the fetal membranes may simply be indicative of the continued presence of BNC.

Anderson et al. (1975) and Steele et al. (1976) demonstrated an increase in the activity of the $\mathrm{C} 17,20$-lyase of ovine placental tissue in response to corticoids in vitro. Mann et al. (1975) also demonstrated an increase in ovine placental aromatase activity in response to corticoids. Our results demonstrate that the action of corticoids on oestrogen synthesis by cow placenta during late gestation

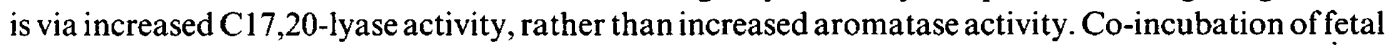
villi minces with dexamethasone was ineffective whereas preincubation with dexamethasone was effective in increasing fetal villi steroid synthesis, especially oestrogen synthesis, from pregnenolone substrate. This indicates that the effect of dexamethasone on placental steroid synthesis is not immediate and that an induction process may be involved. Our data also indicate that the ability to convert androstenedione to oestrogens (aromatase activity) is present in bovine fetal placental 
tissue from late gestation through the early post-partum period. This suggests that the ability of the fetal placental tissue to produce oestrogens is limited by the availability of synthetically earlier precursors than androstenedione.

Overall, our results indicate that the fetal placenta of the cow may be involved in pregnancy maintenance via at least limited progesterone production and in parturition via oestrogen synthesis. Differences in oestrogen synthesis were observed in the post-partum villi minces relative to normal or abnormal fetal membrane separation. Fetal placental binucleate cells (BNC) are the primary source of placental steroids in the cow and a decline in the number of BNC may therefore be important to placental separation. The function of BNC in other synthetic processes and the cause of their decline in numbers at normal parturition need to be determined.

Scientific Article No. A-4703, Contribution No. 7699, of the Maryland Agricultural Experiment Station. Supported in part by USDA-NE-72 Regional Project.

\section{References}

Ainsworth, L. \& Ryan, K.J. (1966) Steroid hormone transformations by endocrine organs from pregnant mammals. I. Estrogen biosynthesis by mammalian placental preparations in vitro. Endocrinology 79, $875-883$.

Anderson, A.B., Flint, A.P.F. \& Turnbull, A.C. (1975) Mechanism of action of glucosteroids in induction of ovine parturition: effect on placental steroid metabolism. J. Endocr. 66, 61-70.

Bjorkman, N. (1969) Light and electron microscope studies on cellular alterations in the normal bovine placentome. Anat. Rec. 163, 17-30.

Butcher, R.L. (1977) Changes in gonadotropins and steroids associated with unilateral ovariectomy of the rat. Endocrinology 101, 830-840.

Chew, B.P., Erb, R.E., Zamet, C.N., Colenbrander, V.B., Malven, P.V. \& D'Amico, M.F. (1979) Variables associated with peripartum traits in dairy cows. Theriogenology 12, 245-255.

English, J.E. (1981) A powerful, yet easy to use, computerized analysis of competitive protein binding and radioimmunoassay data. Computer Programs Biomed. 13, 225-238.

Estergreen, V.L., Frost, O.L., Gomes, W.R., Erb, R.E. \& Bullard, J.F. (1967) Effect on ovariectomy on pregnancy maintenance and parturition in dairy cows. $J$. Dairy Sci. 50, 1293-1295.

Evans, G. \& Wagner, W.C. (1981) In vitro placental estrogen synthesis by bovine placenta during pregnancy and induced parturition. Acta endocr., Copenh. 98, 119-125.

First, N.L. (1978) Mechanisms controlling parturition in farm animals. In Beltsville Symposia In Agricultural Research 3: Animal Reproduction, pp. 215-257. Ed. H. W. Hawk. John Wiley \& Sons, New York.

Garverick, H.A., Day, B.N., Mather, E.C., Gomez, L. \& Thompson, G.B. (1974) Use of estrogen with dexamethasone for inducing parturition in beef cattle. $J$. Anim. Sci. 38, 584-590.

Gross, T.S., Williams, W.F., Galina, C.S., Manspeaker, J., Haaland, M.A. \& Russek, E. (1985a) Functional status of the peripartum bovine corpus luteum. Anim. Reprod. Sci. 8, 193-201.
Gross, T.S., Williams, W.F. \& Manspeaker, J.E. (1985b) Peripartum changes in fetal placental binucleate cell numbers, viability and plasma membrane fragility. $J$. Cell Biol. 101 (Suppl. 1), 321, Abstr.

Hoffmann, B., Wagner, W.C., Rattenberger, E. \& Schmidt, J. (1977) Endocrine relationships during late gestation and parturition in the cow. In The Fetus and Birth (Ciba Fdn Symp. No. 47), pp. 107-118. Elsevier/Excerpta Medica, Amsterdam.

Holm, L.W. Salvatore, C. \& Zeek-Minning, P. (1964) The histology of the postterm bovine placenta. Am.J. Obstet. Gynec. 83, 479-486.

Knight, J.W., Bazer, F.W., Thatcher, W.W., Franke, D.E. \& Wallace, A.D. (1977) Conceptus development in intact and unilaterally hysterectomized, ovariectomized gilts: interrelations among hormonal status, placental development, fetal fluids and fetal growth. J. Anim. Sci. 44, 620-637.

Mann, M.R., Curet, L.B. \& Colas, A.E. (1975) Aromatizing activity of placental microsomal fractions from ewes in late gestation. $J$. Endocr. 65, 117-125.

Margolis, M.J., Williams, W.F., Davidson, J.P. \& Douglass, L.W. (1983) Placental necrosis and giant cell numbers in relation to placental retention in cows. J. Anim. Sci 57, (Suppl. 1), 355. Abstr.

Mostl, E., Choi, H.S. \& Bamberg, E. (1984) In vitro steroid metabolism in cells of the bovine placenta. Proc. 10th Int. Congr. Anim. Reprod. and A.I., ChampaignUrbana, Abstr. 93.

Reimers, T.J., Ullmann, M.B. \& Hansel, W. (1985) Progesterone and prostanoid produetion by bovine nucleate trophoblastic cells. Biol. Reprod. 33, 1227-1236.

SAS (1982) Statistical Analysis System Institute, Inc. Cary, N.C.

Steele, P.A., Flint, A.P.F. \& Turnbull, A.C. (1976) Increased utero-ovarian androstenedione production before parturition in sheep. J. Reprod. Fert. 46, 443-445.

Wagner, W.C., Thompson, F.W., Evans, L.E. \& Molokwu, E.C.I. (1974) Hormonal mechanisms controlling parturition. J. Anim. Sci. 38, (Suppl. 1), 39-57. 
Wiener, M. (1976) Control of placental 3-hydroxy 5 steroid dehydrogenase: comparison of enzyme characteristics in man, cow, goat, rat and rhesus monkey. Biol. Reprod. 14, 306-313.

Williams, W.F., Margolis, M.J., Manspeaker, J., Douglass, L.W. \& Davidson, J.P. (1987) Peripartum changes in the bovine placenta related to fetal membrane retention. Theriogenology 28, 213-224.

Wimsatt, W.A. (1951) Observations on the morphogenesis, cytochemistry and significance of the binucleate giant cells of the placenta of ruminants. Am. J. Anat. 89, 233-281.
Wise, T.H. \& Fields, M.J. (1978) Analysis for the 5 steroid reductase in the bovine ovary with progesterone ${ }^{14} \mathrm{C}$ and testosterone ${ }^{14} \mathrm{C}$. J. Steroid Biochem. 9, $1207-1226$.

Wooding, F.B.P. (1983) Frequency and localization of binucleate cells in placentomes of ruminants. Placenta 4, 527-540.

Wooding, F.B.P. \& Wathes, D.C. (1980) Binucleate cell migration in bovine placentome. J. Reprod. Fert. 59, $425-430$.

Received 17 August 1987 